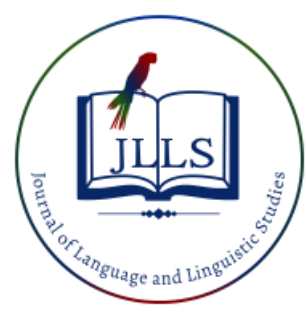

Available online at www.jlls.org

JOURNAL OF LANGUAGE AND LINGUISTIC STUDIES

ISSN: 1305-578X

Journal of Language and Linguistic Studies, 17(3), 1225-1242; 2021

\title{
Reading interest strength and vocabulary acquisition of EFL learners:
}

\section{A meta-analysis}

Eka Santi $^{\text {a }}$ iD, Rochmawati Kholipa ${ }^{\text {b }}$ iD, Marina Gratciana Putri ${ }^{c}$ iD, Mujiono d 1 iD

\section{APA Citation:}

${ }_{a, b, c, d}$ Universitas PGRI Kanjuruhan, Malang, Indonesia

Santi, E., Kholipa, R., Putri, M.G., \& Mujiono. (2021). Reading interest strength and vocabulary acquisition of EFL learners: A metaanalysis. Journal of Language and Linguistic Studies, 17(3), 1225-1242. Doi: 10.52462/jlls.87

Submission Date:04/03/2021

Acceptance Date:20/06/2021

\begin{abstract}
The purpose of this study was to examine the relationship between reading interest strength and vocabulary acquisition in English as a Foreign Language (EFL) learners through a systematic review and meta-analysis of eleven relevant studies conducted over the last decade, from 2010 to 2020 . This study attended by the guidelines of PRISMA. Several stages conducted, such as; identifying the problem, collecting the data, screening, assessing the data, and extracting the data. The data was gathered from peer-reviewed journal articles indexed in databases such as Google Scholar, DOAJ, and Science Direct. Jamovi 1.6.7 was applied to analyze the data. This study aimed to report findings of a meta-analysis assessing correlation among reading interest and vocabulary acquisition. The result obtained was a relatively high relation in reading interest and vocabulary acquisition with pooled correlation $=.485(95 \% \mathrm{CI}=.120$ to -.850$)$. The workings between variables were positive, which meant the students read more and increased vocabulary acquisition. Reading lots of text could improve students' vocabulary acquisition. The reading interest strength could develop vocabulary acquisition for EFL learners.
\end{abstract}

Keywords: reading interest strength; vocabulary acquisition; systematic review; EFL learners; and meta-analysis

\section{Introduction}

Generally, English has been taught as a nonnative language in Indonesia (Kagan \& Özdemir, 2013). It indicates that English has not been used as a means of daily communication in Indonesia. Therefore, as a foreign language learner, reading and mastering vocabulary is an essential element that teachers must teach in English (Oscarini \& Bhakti, 2018; Wulandari, 2019). Students get new vocabulary when reading and comprehend some English words (Bi, 2020). By reading, they can find the meaning of the vocabulary (Tager-Flusberg, 2015). This statement is supported by the study conducted by Rahayuningsih (2020) that to understand the context of a reading, students not only read and pronounce a few words, but students must understand the meaning of each word. In short, reading can increase students' vocabulary (Yildirim, 2008). Reading also makes a person more innovative and more creative. A study conducted by Fitria (2019) stated that when students comprehend what they are reading, the more they read, the better they understand each word meaning in English (Fitria, 2019).

\footnotetext{
${ }^{1}$ Corresponding author.

E-mail address: moejie_nova@unikama.ac.id
} 
Vocabulary is a fundamental ability that students should master to support them in comprehend reading texts. Vocabulary development is significant in improving students' language skills (Pezoa et al., 2019; Yousefi \& Biria, 2018). Readers will comprehend the texts once they have a high vocabulary because vocabulary is important to foreign language mastering (Reynolds et al., 2018). Vocabulary also allows us to prepare our thoughts, feeling, and experiences.

Experts perform numerous previous studies on reading interest and vocabulary acquisition. The first study carried out by Novita \& Juita (2020) showed positive results in testing the impact of reading and dominating vocabulary on description writing skills. This approach used in these studies is correlational quantitative descriptive. Yang et al. (2020) revealed their study using quantitative techniques with a quasi-experimental study and a positive correlation. Third, research conducted by Pecorari et al. (2019) proved a positive result about reading interest and vocabulary acquisition. Other studies were conducted by Kigel et al. (2015), Mousavi \& Gholami (2014), Sparapani et al. (2018) reported a positive resultabout interest in reading and vocabulary acquisition. The research was done by Fitria (2019); Rahayuningsih (2020) also got positive results from their study on reading interest and vocabulary mastery using survey and quantitative methods. A study conducted by Farha \& Rohani (2019), Neumann et al. (2020) also showed positive and significant reading interest and vocabulary mastery results. Şen \& Kuleli (2015) have stated that reading and vocabulary mastery correlate positively.

There are numerous differences between the previous study with this current study. The previous study was conducted using survey techniques, correlational and descriptive quantitative. The sample used in that study was junior high school students. However, researchers want to explore the correlation between reading interest and vocabulary acquisition using systematic literature review and meta-analysis. The purpose of this paper is to present the findings of a meta-analysis examining the relationship between reading interest and vocabulary acquisition in English learners.

\subsection{Research Questions}

The research question of this study is:

To what extent is the reading interest necessary for developing vocabulary acquisition of EFL learners?

\section{Review of Related Literature}

\subsection{The Process of Reading and Reading Interest}

Reading is an essential mode for successful learning in a school setting, and competent reading goes beyond decoding as it also includes text comprehension (Zaccoletti et al., 2020). While reading, a person engages in activities that involve moving the eye muscles to see the text, images, and reading being read. The process of eye movement and attention to the text makes the neural mechanism developmental (Eskenazi \& Folk, 2015). A study conducted by Price (2012) revealed that orthographic processing and phonological processing are supported models in reading. Behavioral, modelling, and neuroimaging experiment involved the process of reading (Cattinelli et al., 2013).

Farha \& Rohani (2019) state that reading is a language skill that is very important to support success in obtaining knowledge or information. When reading, the primary cognitive or reasoning process works (Zhou et al., 2021). Based on Hall et al. (2019), reading is an activity to catch, understand, know, or get the literal pattern information. 
Bojovic (2010) states that the process of obtaining and carrying the meaning of a text is called reading comprehension. It is the fundamental way to get and learn new information. Babayiğit (2014) argued that reading comprehension's more significant contribution is vocabulary knowledge and linguistic comprehension. Reading comprehension contributes to nature understanding, linguistic development, and skill, i.e., vocabulary knowledge, grammatical skill, and morphological knowledge (Cervetti et al., 2019). The main important component in reading comprehension for English learners is vocabulary and comprehending oral language (Spencer \& Wagner, 2018). An activity that is helpful to get more knowledge or information is reading comprehension.

According to Soriano-Ferrer \& Morte-Soriano (2017), an activity that makes the students motivated in reading is reading the text related to the theme they liked. Several aspects also influence reading motivation; engaging text, interpersonal, family or friends (social context), subject matter, or text genre. Almekhlafy \& Alqahtani (2020) defined reading motivation as an essential factor, which plays a crucial role in reading development. Two factors influence the students' motivation based on a study conducted by Almekhlafy \& Alqahtani (2020); motivated by themselves (intrinsic motivation) and motivated from outside (extrinsic motivation) (Almekhlafy \& Alqahtani, 2020). These factors (intrinsic and extrinsic) can build the students' interest in reading (Rachmawati, 2018).

According to Rachmawati (2018), reading interest is someone's interest in reading. A person's interest in reading can be influenced by several factors such as encouragement from people around them, habits, to the reading material they use to read. Reading interest is necessaryfor learners to triumph. Therefore, it takes a high level of interest in reading (Khairuddin, 2013). Someone wants to read because they need to get information and knowledge (Önalan, 2005). In other words, interest in reading is a powerful desire followed by a feeling of pleasure to read (Walgermo et al., 2018). Based onWigfield (2015), reading interest plays an essential position to achieve reading goals (getting knowledge and information).

In short, reading belongs to a cognitive activity that can make the students or readers get new information or knowledge by understanding the text. It also can motivate the students or readers to read the text. Intrinsic and extrinsic motivation are factors that influenced the students in reading. Interest in reading is a desire of someone who has been supported by high self-motivation. Through reading, students will get new information and knowledge by understanding the text. Reading interest can be proven by a person's willingness to look for reading material to read following the reading of interest.

\subsection{The Essential of Vocabulary Acquisition}

An essential element in language learning is vocabulary. Through language, someone can deliver ideas and feelings (Karagöz et al., 2014). Vocabulary is not only words but also meaning to help someone express existing ideas appropriately (Hariati, 2020). Vocabulary always appears in language skills (reading, listening, speaking, and writing) because it is vital in learning a foreign language. Besides foreign language, vocabulary is also a crucial aspect in second language learning (Sanosi, 2018). This statement supported the study conducted by Bi (2020), which stated that vocabulary is necessary to learn English.

There are several essential elements in learning a language in affecting the learners, such as students' motivation, students' giftedness, and the learning strategies to get new vocabulary (Leona et al., 2021). According to Muñoz (2017), factors that influence the students' motivation for vocabulary acquisition are enjoyable and satisfying activities. Students' gifted in vocabulary acquisition refer to the students' talent in learning the language to understand and memorize the new vocabulary (Çakır, 2014). Strategy in learning is acquired the students' vocabulary acquisition (Alharthi et al., 2020; Vela 
\& Rushid, 2016). Students' talent the vocabulary) can help foreign language learners or second language learners achieve language skills. For example, the language learners can speak when they know the words or vocabulary that they want to deliver to the listeners. Likewise, the listeners will understand what the speaker has spoken. The EFL learners will write and express their idea through written form when they know the vocabulary. Reading is a basic language skill that can help language learners get new vocabulary knowledge (Shahraki \& Kassaian, 2011). According to Subon (2016), vocabulary knowledge is an essential element for foreign language learners or second language learners in achieving language acquisition. Based on the study conducted by Mahdavy (2011), extensive reading can help to achieve the students' vocabulary acquisition.

Vocabulary acquisition is an aspect that is necessary for teaching and learning language (Zhonggen, 2018). Thompson \& von Gillern (2020) stated that vocabulary acquisition could develop language skills. Therefore, vocabulary is essential for writing, listening, reading, and speaking supported by general language proficiency. A large amount of new vocabulary is necessary to succeed with language learning. Vocabulary acquisition is the primary and crucial aspect of learning a foreign and second language. It means the language learners needed that vocabulary.

\subsection{The relationship between Reading Interest and VocabularyAcquisition}

Research has established that vocabulary development is highly affected by extensive reading (Chun et al., 2012). Based on the study conducted by Alsaif \& Masrai (2019), extensive reading can enrich the learners" vocabulary. Reading the text allows the learners to read and understand the text and receive the vocabulary (Moghadam et al., 2012). According to Iftanti \& Shofiya (2018), extensive reading effectively contributes to English learners' increasing English competence and good reading habits. It also develops reading comprehension, vocabulary, grammar, writing, speaking, and listening for both second and foreign language learners. The other study showed that extensive reading could increase vocabulary acquisition (Chavangklang et al., 2019).

Study about reading and vocabulary did quantitatively by several experts. One of them is the study conducted by Farha \& Rohani (2019). They reported that reading cognition could improve the students' sense of a text, motivating, and word stock (Farha \& Rohani, 2019). If the students understand the vocabulary, they can easily comprehend the text and build their reading interest (Fitria, 2019). Targets several things, including motivation and repetition, help students understand their reading comprehension (Rumainah, 2018). According to Rahayuningsih (2020), students' understanding was mainly attributable to their reading habits and vocabulary acquisition. Students' who have higher reading habit, they also have higher reading comprehension. To achieve reading comprehension, the students need to master vocabulary to guess the reading text (Rahayuningsih, 2020). Kigel et al. (2015) stated that to avoid the students' poor reading skills, it needed to give training that focuses on comprehending the text and mastering the vocabulary. Achieve Neumann's study (2020) by understanding to master text and the vocabulary, making the learners increase writing skill (Neumann et al., 2020). This statement is also supported by the study conducted by Novita \& Juita (2020), which claims that reading interest and vocabulary mastery gave a higher contribution to students' writing skills (Novita \& Juita, 2020). Writing skills, reading comprehension, and vocabulary acquisition also contribute to the learners' social skills (Sparapani et al., 2018). (Mousavi \& Gholami, 2014) stated that using media in learning English has a positive effect. Their study showed that by watching flash and reading the subtitle was improved the vocabulary acquisition of students. Vocabulary acquisition contributed to the learners social can offer contributed to' vocabulary knowledge (skill sari et al., 2019). Another media in vocabulary learning is learning based on the game. The learners can read the message on the game or make the game's conversation (Yang et al., 2020). In light of these findings, it can be said that reading and understanding language appears to be 
dependent on one's vocabulary. It also supports Ibrahim et al. (2016) 's statement the students need an essential component, namely vocabulary knowledge, in improving reading comprehension.

\section{Method}

\subsection{Research Design}

The researchers used a systematic literature review (SLR) method. It was used to systematically identify, analyze, interpret, and evaluate journals that follow predefined steps. The systematic literature review indicates the objective approach (clear set of rules) used to recognize the proper studies (Impellizzeri \& Bizzini, 2012). It discussed the relevant inclusion, exclusion criteria, and a well-defined methodological analysis of chosen studies. The possibility of research bias was reduced if an SLR was carried out appropriately.

The researchers used a meta-analysis in analyzing the data. It is based on PRISMA (Fraihat et al., 2019; Hoque et al., 2017; Sibbritt et al., 2018). According to Shelby \& Vaske (2008), meta-analysis systematically collects, synthesizes, and analyzes various reviews. A statistical device that is stable research and an authentic research method is called meta-analysis (Impellizzeri \& Bizzini, 2012).

By the PRISMA guidelines, SLR searches were carried out using SLR studies' journals Scopus published from 2010 to 2020. Combining individual studies conducted by previous investigators enables in providing the estimate of the effect of the treatment. The quantitative synthesis of various studies is valid if the studies have been analyzed and gathered reasonably and systematically. Both SLR and meta-analysis are generally applied together. To obtain an accurate estimate, utilize the same population, methodology, and design. Literature search uses keywords relevant to the variables studied.

\subsection{Different Stages of a Systematic Review}

Numerous systematic literature reviewsare needed to make the findings credible. Detailed procedures for the systematic review is provided in the picture above. To identify the issues, we utilize three main sources: Google Scholar, DOJ, and Science Direct.From these three sources, we identify $(n=135.000)$ articles from Google Scholar, $(n=2.220)$ DOAJ, and $(n=1.689)$ Science Direct. The researchers collected the data from those websites in articles that identified problems related to reading interest and vocabulary acquisition $(\mathrm{n}=138,909)$ articles. The researcher selects or filters data according to the topic to be studied, then filtered based on criteria; 1) the published Journals are not more than ten years (2010-2020), 2) Journal type (review articles, research articles), and 3) Full-text access to our papers from those criteria, the researchers found $(n=18.000)$ articles in Google Scholar $(\mathrm{n}=2.220)$ DOAJ, $(\mathrm{n}=820)$ Science Direct. Next, the researchers measure the quality of the journals by determining inclusion criteria such as 1) Journals are full text, 2) Journals that related to Reading Interest and vocabulary Acquisition 3) Journals discussed reading interest and vocabulary acquisition 4) Journals used a quantitative approach. Therefore, it was collected $(n=13)$ Google Scholar $(n=14)$ DOAJ, $(n=13)$ Science Direct, $(n=11)$ for the journals used quantitative approach. Lastly, the researcher extracts the data by searching and calculating all the journals that use the quantitative approach. It was found $(n=11)$ journals used a quantitative approach. 


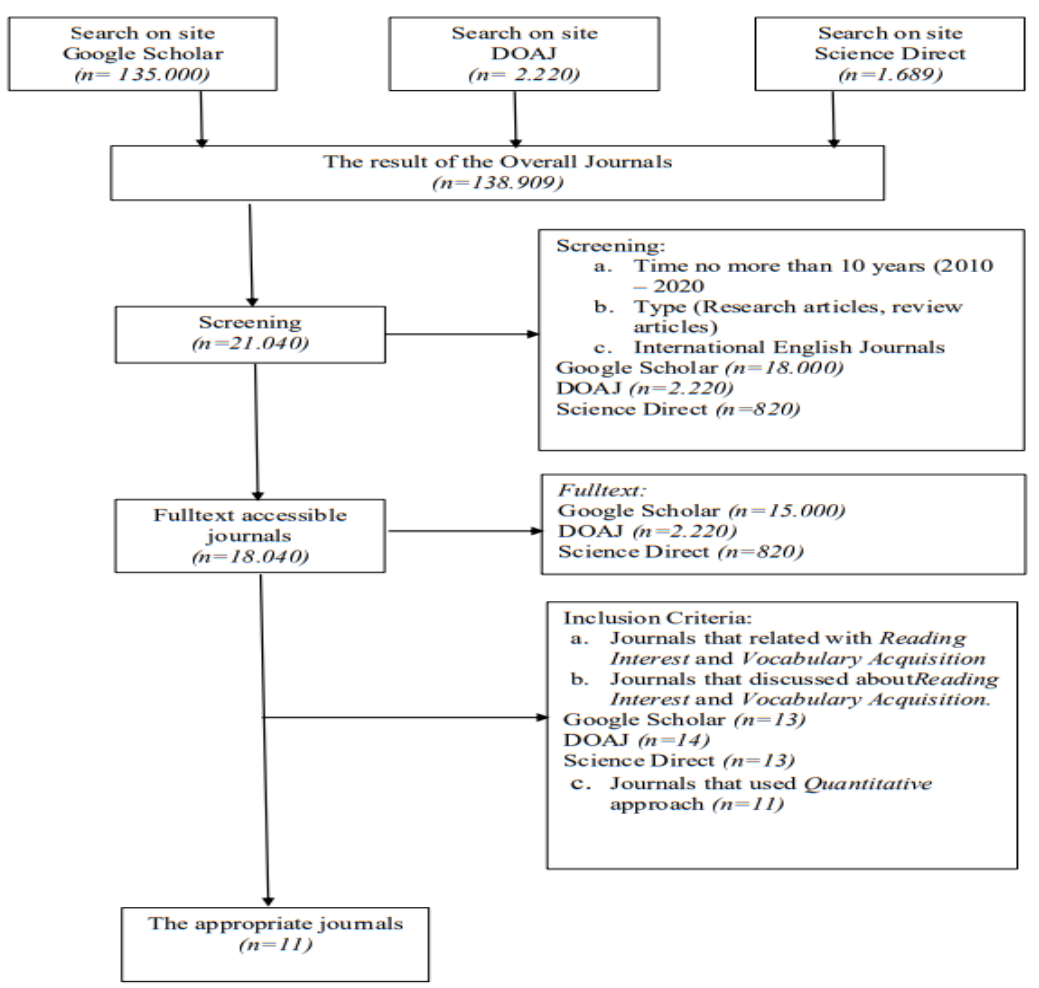

Figure 1. Systematic Literature Review

\subsubsection{Identifying the Problems}

Problem identification is an inventory of problems. The most important and fundamental of the other components is the research problem. To determine the quality of the research, researchers must include several issues. In this study, researchers examined various problems through international research journals derived from research reports. The issues in this research were Reading Interest and Vocabulary Acquisition.

\subsubsection{Collecting the Data}

The researchers applied several websites to access the journals, such as Google Scholar, DOAJ, and Science Direct, to collect the data. Based on the title examined, "The Investigation of Reading Interest and Vocabulary Acquisition: Systematic Literature Review and Meta-Analysis," the researchers utilized some keywords such as "Reading Interest" and "Vocabulary Acquisition" to find out the appropriate journals. The researchers also used a service to remove all the barriers to finding out the relevant journals.

\subsubsection{Screening}

Screening is one of the SLR method stages, where the researcher selects or filters data according to the topic to be studied. The issues examined in this study are "The Investigation of Reading Interest and Vocabulary Acquisition: Meta-Analysis." Journals are collected, then filtered based on criteria; 1) the published Journals are not more than ten years (2010-2020), 2) Journal type (review articles, research articles), and 3) Journals that can be accessed full text.

\subsubsection{Assessing the Quality}

The SLR method's quality assessment is the assessment of journal data sources suitable for use as a reference in preparing SLR research, which is the purpose of these journals to be further analyzed. The 
quality of journals' characteristics, as 1) Journals are full text, 2) They fit the study needs of vocabulary and reading interests magazines considered reading and vocabulary acquisition were designed to use a quantitative approach.

\subsubsection{Extracting the Data}

Researchers could do the data extraction if all data that met the requirements (in the screening stage) are filtered. It could be known for sure from the amount of data that still meets the further analysis requirements. The researcher extracts the data by searching and calculating all the journals that use the quantitative approach.

\subsection{Population, Sampling Techniques, Sample, and variables}

\subsubsection{Population}

The population is a subject that fulfils the criteria set by the researcher. The population's criteria in this study were international journals related to students' interest in reading and vocabulary acquisition. The population used is 138,909 .

\subsubsection{Sampling Technique}

The sampling method is a process of choosing numerous criteria from the population to represent the population. This procedure was used to collect representative samples from all research participants. The study applied the purposive sampling technique. The purposive sampling approach is a pattern determination technique by deciding on a sample most of the population according to the study's objectives and issues. The sample can constitute previously acknowledged population characteristics. The previous population's characteristics mentioned two criteria in this research: inclusion and exclusion.

Inclusion Criteria. The inclusion criteria used in the sampling technique of this study such as; 1) International journals related to "Reading Interest" and "Vocabulary Acquisition," 2) International journals discussed "Reading Interest" and "Vocabulary Acquisition."

Exclusion Criteria. The exclusion criteria used in the sampling technique of this study such as; 1) the correlation between "Reading Interest" and "Vocabulary Acquisition," and 2) the effect of "Reading Interest" and "Vocabulary Acquisition."

\subsubsection{Sample}

The sample was used as research subjects through sampling. Two conditions must be fulfilled in determining the sample; namely, the first is representative. The sample can represent the existing population, and the second, the sample must be sufficiently large. The samples in this study were 11 journals related to reading interest and vocabulary acquisition.

\subsubsection{Variables}

This study's variable can be defined as an attribute, nature, or value of people, objects, or activities with the researcher's particular variations. This study's independent variable was reading interest, while the dependent variable in this study was vocabulary acquisition.

\subsection{Data Analysis}

In collecting the data, the researchers collected secondary data from published research results from experts. The researchers' quality of each journal is of a high standard or indexed by Scopus, which uses three websites to find the journals, Google Scholar, DOAJ, and Science Direct. The researchers took journals in English, which used a quantitative research design or related to numbers 
and contained correlation results. The researcher has determined the following table as a sample, which was listed in table 1:

Table 1. List of eleven studies

\begin{tabular}{|c|c|c|c|c|c|c|c|c|}
\hline Author/Year & Country & Sample & Age & Gender & Correlation & SD & Mean & $\mathbf{r}$ \\
\hline $\begin{array}{l}\text { Farha \& Rohani, } \\
2019\end{array}$ & Indonesia & 71 & 16 & $\begin{array}{l}\text { Male \& } \\
\text { Female }\end{array}$ & .000 & - & 90.97 & - \\
\hline Fitria, 2019 & Indonesia & 47 & 14 & $\begin{array}{l}\text { Male \& } \\
\text { Female }\end{array}$ & .001 & 11.866 & 76.26 & .986 \\
\hline $\begin{array}{l}\text { Kigel, et al., } \\
2015\end{array}$ & Germany & 712 & 9.1 & Female & .500 & 1.30 & 3.54 & .41 \\
\hline $\begin{array}{l}\text { Mousavi And } \\
\text { Gholami, } 2014\end{array}$ & Iran & 28 & 10.5 & $\begin{array}{l}\text { Male \& } \\
\text { Female }\end{array}$ & .001 & 19.47 & 19.47 & - \\
\hline $\begin{array}{l}\text { Neumann et al., } \\
2020\end{array}$ & Canada & 60 & 20.7 & $\begin{array}{l}\text { Male \& } \\
\text { Female }\end{array}$ & .032 & 2.802 & 5.34 & $\begin{array}{l}- \\
.367\end{array}$ \\
\hline Novita, 2020 & Indonesia & 108 & 16 & $\begin{array}{l}\text { Male \& } \\
\text { Female }\end{array}$ & .944 & - & 72.55 & - \\
\hline $\begin{array}{l}\text { Pecorari et al., } \\
2019\end{array}$ & $\begin{array}{l}\text { Hong } \\
\text { Kong }\end{array}$ & 114 & 21.5 & $\begin{array}{l}\text { Male \& } \\
\text { Female }\end{array}$ & .870 & 9.83 & 41.61 & .54 \\
\hline $\begin{array}{l}\text { Rahayuningsih, } \\
2020\end{array}$ & Indonesia & 30 & 17 & $\begin{array}{l}\text { Male \& } \\
\text { Female }\end{array}$ & .722 & - & 36.908 & .722 \\
\hline Rumainah, 2018 & Indonesia & 86 & 20.5 & $\begin{array}{l}\text { Male \& } \\
\text { Female }\end{array}$ & .016 & 11.949 & 137.36 & $\begin{array}{l}- \\
.016\end{array}$ \\
\hline $\begin{array}{l}\text { Sparapani et al., } \\
2018\end{array}$ & California & 486 & 8.5 & Male & .420 & 0.44 & 6.6 & .45 \\
\hline $\begin{array}{l}\text { Yang et al., } \\
2020\end{array}$ & $\begin{array}{l}\text { Hong } \\
\text { Kong }\end{array}$ & 51 & 17 & $\begin{array}{l}\text { Male \& } \\
\text { Female }\end{array}$ & .210 & 12.72 & 72.24 & - \\
\hline
\end{tabular}

Based on the table above, the researchers listed five categories. 2 categories were calculated and conclude the results in this study through the Jamovi application, samples, and correlation results of each journal. Thus, the results of these calculations can be presented in Table 2 and the forest plot.

\section{Result}

Table 2. The pooled correlation coefficient

Random-Effect Model (k=11)

\begin{tabular}{lllllll}
\hline & Estimate & Se & $\mathbf{Z}$ & $\mathbf{p}$ & $\begin{array}{l}\text { CI Lower } \\
\text { Bound }\end{array}$ & $\begin{array}{l}\text { CI Upper } \\
\text { Bound }\end{array}$ \\
\hline Intercept & .485 & .186 & 2.60 & .009 & .120 & .850 \\
\hline
\end{tabular}

As presented in table 2, the eleven studies that have been analyzed showed the pooled correlation coefficient represents $0.485, \mathrm{p}=0.009$. As an addition, the $\mathrm{p}$-value did calculate the hypothesis accepted or rejected. Based on the meta-analysis, the p-value points out 0.009 with a significant level of $95 \%$. A summary could be: reading interest and vocabulary acquisition greatly influenced how well the students learned to read. 
Table 3. Heterogeneity Statistic

\begin{tabular}{llllllll}
\hline Tau & Tau $^{2}$ & $\mathbf{I}^{2}$ & $\mathbf{H}^{2}$ & $\mathbf{R}^{2}$ & $\mathbf{D f}$ & $\mathbf{Q}$ & $\mathbf{p}$ \\
\hline 0.604 & $\begin{array}{l}0.3651 \\
(\mathrm{SE}=0.1707)\end{array}$ & $97.96 \%$ & 49.089 &. & 10.000 & 319.574 & $<.001$ \\
\hline
\end{tabular}

In table 3 , The I2 equation specified the variables as moderate or low. It was considered with the heterogeneity. Thus, the heterogeneity statistic presented the $\mathrm{I}^{2}=97.96 \%$. It means that eleven studies that have been analyzed were very heterogenic. The data is heterogeneous if the value of $\mathrm{I}^{2}$ shows a result of more than $50 \%$.

Table 4. Publication Bias Assessment

\begin{tabular}{lll}
\hline Test Name & Value & P \\
\hline Fail-Safe N & 1470.000 & $<.001$ \\
Kendalls Tau & -0.055 & 0.879 \\
Egger's Regression & -0.812 & 0.417 \\
\hline
\end{tabular}

Note. Fail-safe N Calculation Using the Rosenthal Approach

To obtain the information and evaluation of research results, which show the correlation between reading interest and vocabulary acquisition from missing or unpublished journal articles, it needs to assess the bias publication. Table 4 showed publication bias from eleven studies, which calculate by using JAMOVI 1.6.7 software. From the publication bias assessment table, Fail-Safe N's value was 1470, which calculate by using the Rosenthal approach. The p-value of the Rosenthal approach was $<.001$, which meant the eleven studies involved were significant. As a result, it was determined that 1470 journals were not considered significant. Kendall was involved in a study that sought to find the relationship among students' attracted in reading and vocabulary acquisition. It showed -0.055 with a p-value of 0.485 , which is more than 0.05 . It can be concluded a publication bias was not found.

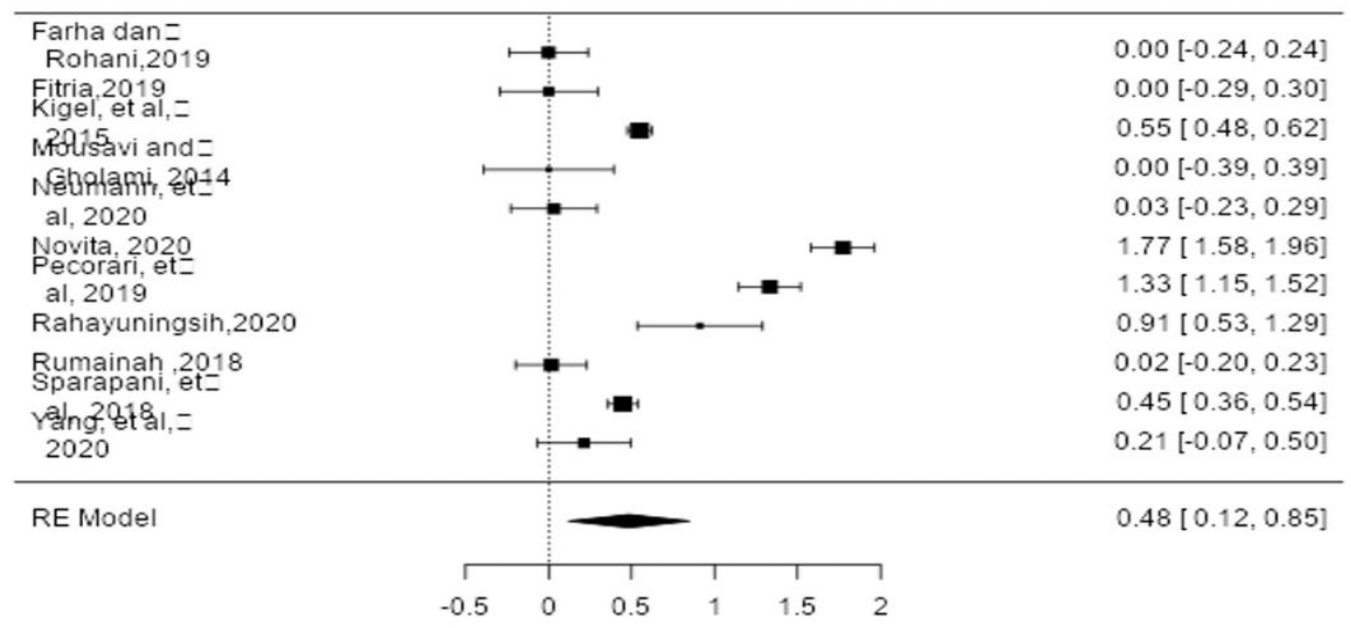

Figure 2. Forest Plot

Figure 2, The left column showed the studies used as the data collection in this study. The strip-line can be called a no-effect line. The black square represented the point estimate of the effect size of each study. The line on the sides of Black Square represented the confidence interval of $95 \%$. The right 
column represents the estimated value, CI lower bound, and CI upper bound. The black diamond below represents the estimated value of overall studies. Based on figure 2, the random effect model's diamond showed on the right side of the no-effect line with the estimated value of 0.48. Overall, studies appeared a significant correlation between vocabulary acquisition and reading interest.

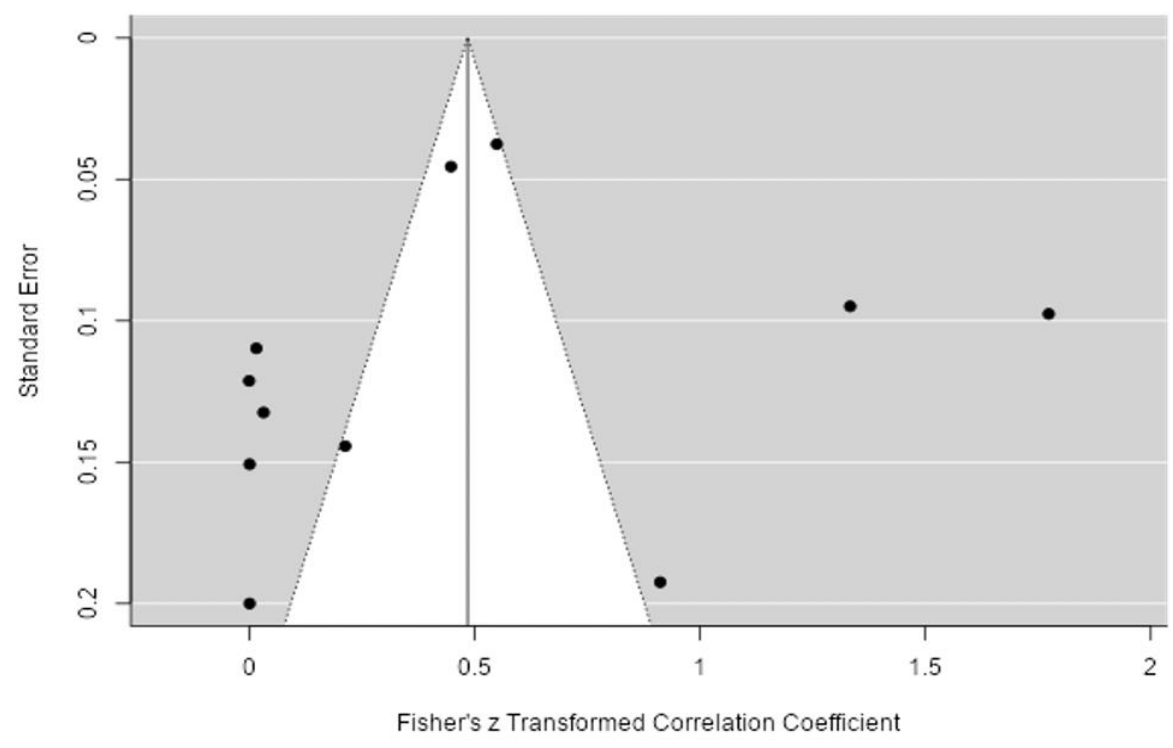

Figure 3. Funnel Plots of publication bias

The researchers applied a "funnel plot" to present the reasons for publishing bias in the metaanalysis. The defined outcomes the reading interest variable's impact on vocabulary acquisition. As seen in figure 3, the funnel plot reveals no bias, which means the study has a positive result. In short, more information is needed about the causes or factors that can affect students' attraction to reading and students' vocabulary acquisition.

As a result of the data analysis shown above, it was clear that there was a relationship between students' interest in reading and their vocabulary acquisition..

\section{Discussion}

This paper aimed to determine the correlation between students' reading interest and vocabulary acquisition, which was done using a systematic literature review and meta-analysis. Several stages (i.e.e identifying problems, gathering the data, screening, and compiling the assessment were all done to obtain the sample. The eleven studies collected as a sample and counted it through Jamovi software. The result obtained was a relatively moderate relationship between reading interest and vocabulary acquisition with pooled correlation $=.485(95 \% \mathrm{CI}=.120$ to -.850$)$. These meta-analysis findings were consistent with past literature that has reported that vocabulary interest was positively associated with vocabulary acquisition.

The study conducted by Marzban \& Raeisi (2013) showed that the readers would obtain the new vocabulary knowledge by comprehending the text. It is necessary to develop vocabulary. When the learners have more engaged reading text, they will learn more words or vocabulary (Khezrlou \& Ellis, 2017). A recent study about vocabulary showed the essential competence in vocabulary acquisition is reading understanding. The success of reading, listening, speaking, and writing is very predictable when the learners have the extent of vocabulary knowledge (Alavi \& Akbarian, 2012). the research conducted by (Kamal, 2019) showed a beneficial component to extend the word stock. Ismail et al. (2019) reported that encouraging children to read positively impacted their overall language 
development, among other things they found (Ismail et al., 2019). A study conducted by Li and Deng (2018) found that having a more excellent vocabulary via texting is associated with a positive result. They showed that reading vocabulary messages was helpful to support vocabulary learning.

Two studies conducted by Chen \& Yen (2013); Varol \& Erçetin (2016) reported that reading performs a dominant role in vocabulary acquisition. Another study conducted by Ong \& Zhang (2018) stated that reading could improve the students' vocabulary. Code switched approach could be an approach to develop the students' vocabulary acquisition. Neumann et al. (2020) showed a positive result in their study. Prawiyogi et al. (2020) stated that improving their reading interest uses big book media, including texts and pictures. It can build the students' enthusiasm to read and get the vocabulary. Nurdiani et al. (2018), in their study, revealed the significant effect between reading comprehension and vocabulary acquisition. Their result showed that vocabulary mastery helped the contribution to students' writing ability. Swanson et al. (2015) discovered that reading significantly enhanced knowledge acquisition, the quality of content recall, and vocabulary. Vocabulary is a crucial part of text comprehension, and reading comprehension has been recognized by the study conducted by Welie et al. (2017). Their study presented a higher connection between vocabulary and metacognitive knowledge.

According to Numan Khazaal (2019), reading strategy has a significant role in mastering vocabulary. Reading can improve vocabulary (Vidal, 2011). Suk (2017) stated the extensive reading could develop reading skills L2 and increased L2 vocabulary mastery. Wasik et al. (2016); Cervetti et al. (2019); Wasik et al. (2016) displayed by reading and rereading the text can improve vocabulary. The research declares vocabulary mastery is derived from reading. (Pigada \& Schmitt, 2006). The acquisition of English vocabulary can be influenced by reading. (Liu \& Zhang, 2018). Kweon \& Kim (2008), presented a significant vocabulary acquisition for pre-test and post-test 1 . Then, the vocabulary is also obtained in Post-test 2.

On the other hand, several studies showed many EFL learners have a low interest in reading. One of them is the study conducted by Rachmawati (2018). Her study reported the EFL learners did the reading activity when they are in learning processes and when they are in examination (for answering the question) (Rachmawati, 2018). Reading activities has a low significance effect on vocabulary acquisition (Malin et al., 2014). Korat (2010) reported his research results, which showed that both children's groups showed significant development in vocabulary knowledge. Compared to first graders, kindergarten children showed better development of reading words. The outcome obtained were not able to sustain the hypothesis of the research. There is no difference of groups on one measure of vocabulary reading fidelity (Colenbrander et al., 2016).

According to Rachman (2018), the learners who have a low ability to understand the text cause them to be unmotivated in learning English, especially in reading English text. Soriano-Ferrer \& Morte-Soriano (2017) stated students would have motivated to read when they read the engaging text. The interpersonal, family or friends (social context), subject matter, or genre of the text also influences them. In short, reading interest was beneficial for the students' vocabulary acquisition. It supported this study's result, which showed a positive relationship and was supported by the expert's past study. However, this study was constrained by factors that influence students' reading interest on vocabulary acquisition, such as lack of self-motivation and exciting media to read. Therefore, to make the students' interest in reading, they must be motivated and supported by exciting media. The higher selfmotivation, the environment, and the attractive media, the better the students will increase their reading interest. 


\section{Conclusion}

This study discusses reading interest strength in acquiring EFL learners' vocabulary acquisition. Reading interest is one of the alternatives for improving EFL learners' vocabulary acquisition. Vocabulary is the basis of learning English to support abilities in other fields, such as; reading, writing, speaking, and listening. The meta-analyzed findings showed an improvement of reading interest on students' vocabulary acquisition. Therefore, reading interest strength is one of the strategiesto improve learner' vocabulary acquisition.

In conclusion, this can be deduced from previous studies that the more reading they do, the more words they learn. The research conclusion is a brief statement about the systematic analysis results derived from facts or logical relationships and contains answers to the problem formulation section's questions.

The overall response to the questions concerning the topic's scope includes many issues, but the form of the asked problems dictates the numbers. An increased interest in reading can help learners gain in their English vocabulary acquisition.

\section{Acknowledgements}

The researchers would like to thank the Directorate of "BELMAWA" from the Ministry of Education and Culture of Republic Indonesia for providing fundingwith this research through the scheme of "(PKM-R)".

\section{References}

Alavi, S. M., \& Akbarian, I. (2012). The role of vocabulary size in predicting performance on TOEFL reading item types. System, 40(3), 376-385. https://doi.org/10.1016/j.system.2012.07.002

Alharthi, M., Bown, A., \& Pullen, D. (2020). The Use of Social Media Platforms to Enhance Vocabulary Developing in Learning a New Language: A Review of The Literature. Arab World English Journal (AWEJ), 6, 318-331. https://doi.org/https://dx.doi.org/10.24093/awej/call6.21https://dx.doi.org/10.24093/awej/call6.21

Almekhlafy, S. S. A., \& Alqahtani, A. A. J. (2020). The visual memory development technique: A remedial and pre-reading activity to enhance EFL learners' motivation. Heliyon, 6(3), e03627. https://doi.org/10.1016/j.heliyon.2020.e03627

Alsaif, A., \& Masrai, A. (2019). Extensive Reading and Incidental Vocabulary Acquisition: The Case of a Predominant Language Classroom Input. International Journal of Education and Literacy Studies, 7(2). https://doi.org/http://dx.doi.org/10.7575/aiac.ijels.v.7n.2p.39

Babayiğit, S. (2014). The Role of Oral Language Skills in Reading and Listening Comprehension of Text: A Comparison of Monolingual (L1) and Bilingual (L2) Speakers of English Language. Journal of Research in Reading, 37(SUPPL1), 1-26. https://doi.org/10.1111/j.1467-9817.2012.01538.x

Bi, J. (2020). How Large a Vocabulary do Chinese Computer Science Undergraduates Need to Read Englishmedium Specialist Textbooks? English for Specific Purposes, 58, 77-89. https://doi.org/10.1016/j.esp.2020.01.001

Bojovic, M. (2010). Reading Skills and Reading Comprehension in English for Specific Purposes. The International Language Conference on The Importance of Learning Professional Foreign Languages for Communication between Cultures 2010, September 2010, 1-5.

Çakır, L. (2014). The Relationship between Underachievement of Gifted Students and their Attitudes toward School Environment. Procedia - Social and Behavioral Sciences, 152, 1034-1038. 
https://doi.org/10.1016/j.sbspro.2014.09.269

Cattinelli, I., Borghese, N. A., Gallucci, M., \& Paulesu, E. (2013). Reading the Reading Brain: A New MetaAnalysis of Functional Imaging Data on Reading. Journal of Neurolinguistics, 26(1), 214-238. https://doi.org/10.1016/j.jneuroling.2012.08.001

Cervetti, G. N., Pearson, P. D., Palincsar, A. S., Higgs, J., Fitzgerald, M. S., \& Berman, A. I. (2019). How the Reading for Understanding Initiative's Research Complicates the Simple View of Reading Invokes in the SScience of Reading. International Literacy Association: Reading Research Quartetly, 1-12. https://doi.org/10.1002/rrq.343

Chavangklang, T., Chavangklang, P., Thiamhuanok, S., \& Sathitdetkunchorn, P. (2019). Development of EFL University Students' Vocabulary Size and Reading Comprehension Using Online Multimedia-based Extensive Reading. Advances in Language and Literary Studies, 10(5), 146. https://doi.org/10.7575/aiac.alls.v.10n.5p.146

Chen, I. J., \& Yen, J. C. (2013). Hypertext Annotation: Effects of Presentation Formats and Learner Proficiency on Reading Comprehension and Vocabulary Learning in Foreign Languages. Computers and Education, 63, 416-423. https://doi.org/10.1016/j.compedu.2013.01.005

Chun, E., Choi, S., \& Kim, J. (2012). The Effect of Extensive Reading and Paired-Associate Learning on Long-term Vocabulary Retention: An Event-related Potential Study. Neuroscience Letters, 521(2), 125129. https://doi.org/10.1016/j.neulet.2012.05.069

Colenbrander, D., Kohnen, S., Smith-Lock, K., \& Nickels, L. (2016). Individual differences in the vocabulary skills of children with poor reading comprehension. Learning and Individual Differences, 50, 210-220. https://doi.org/10.1016/j.lindif.2016.07.021

Eskenazi, M. A., \& Folk, J. R. (2015). Skipped Words and Fixated Words are Processed differently during Reading. Psychonomic Bulletin and Review, 22(2), 537-542. https://doi.org/10.3758/s13423-014-0682-6

Farha, N. A., \& Rohani, R. (2019). Improving Students' Reading Comprehension of Report Text with KWL Strategy. ELT Forum: Journal of English Language Teaching, 8(1), 25-36. https://doi.org/10.15294/elt.v8i1.30244

Fitria, W. (2019). Reading Interest and Reading Comprehension: A Correlational Study. Journal Educative: Journal of Educational Studies, 4(1), 95. https://doi.org/10.30983/educative.v4i1.1333

Fraihat, N., Madae'En, S., Bencze, Z., Herczeg, A., \& Varga, O. (2019). Clinical Effectiveness and Costeffectiveness of Oral-health Promotion in Dental Caries Prevention among Children: Systematic Review and Meta-analysis. International Journal of Environmental Research and Public Health, 16(15). https://doi.org/10.3390/ijerph16152668

Hall, C., Vaughn, S., Barnes, M. A., Stewart, A. A., Austin, C. R., \& Roberts, G. (2019). The Effects of Inference Instruction on the Reading Comprehension of English Learners With Reading Comprehension Difficulties. Remidial and Special Education. https://doi.org/10.1177/0741932518824983

Hariati, P. (2020). Improving Students' Vocabulary Mastery through Teaching Real Objects. Budapest International Research and Critics in Linguistics and Education (BirLE) Journal, 3(2), 740-748. https://doi.org/10.33258/birle.v3i2.905

Hoque, D. M. E., Kumari, V., Hoque, M., Ruseckaite, R., Romero, L., \& Evans, S. M. (2017). Impact of clinical registries on quality of patient care and clinical outcomes: A systematic review. PLoS ONE, 12(9), 1-20. https://doi.org/10.1371/journal.pone.0183667

Ibrahim, E. H. E., Sarudin, I., \& Muhamad, A. J. (2016). The Relationship between Vocabulary Size and Reading Comprehension of ESL Learners. English Language Teaching, 9(2), 116. https://doi.org/10.5539/elt.v9n2p116

Iftanti, E., \& Shofiya, A. (2018). EFL Students' Responses on The Implementation of Extensive Reading 
Program to Build Love of Reading in English. Jurnal Bahasa Lingua Scientia, 10(1), 143-158. https://doi.org/10.21274/1s.2018.10.1.143-158

Impellizzeri, F. M., \& Bizzini, M. (2012). Invited Commentary. The International Journal of Sports Physical Therapy, 7(5), 493-503. https://doi.org/10.4085/1947-380x-5.4.179

Ismail, Samad, I. S., \& Masnur. (2019). The Impact of Interactive Reading Using Local Folktales Stories in Supporting Students' Vocabulary Achievement in Indonesian EFL Majesty Journal, 2, 25-37. https://doi.org/https://doi.org/10.33487/majesty.v1i2.119

Kagan, R., \& Özdemir, S. (2013). Foreign Language Vocabulary Learning with Mobile Technologies. Procedia - Social and Behavioral Sciences, 83, 781-785. https://doi.org/10.1016/j.sbspro.2013.06.147

Kamal, S. M. (2019). Developing EFL Learners Vocabulary by Reading English Comprehension in EFL Classroom. International Journal of English Language and Literature Studies, 8(1), 28-35. https://doi.org/10.18488/journal.23.2019.81.28.35

Karagöz, M., Yücelşen, N., \& Oryaşın, U. (2014). A Study of Tale Reading Dictionary Framework of Teaching Vocabulary. Procedia - Social and Behavioral Sciences, 152, 943-949. https://doi.org/10.1016/j.sbspro.2014.09.347

Khairuddin, Z. (2013). A Study of Students' Reading Interests in a Second Language. International Education Studies, 6(11). https://doi.org/10.5539/ies.v6n11p160

Khazaal, E. N. (2019). Impact of Intensive Reading Strategy on English for Specific Purposes. Arab World English Journal (AWEJ), 10(2), 181-195. https://dx.doi.org/10.24093/awej/vol10no2.15

Khezrlou, S., \& Ellis, R. (2017). Effects of computer-assisted glosses on EFL learners' vocabulary acquisition and reading comprehension in three learning conditions. System, 65, 104-116. https://doi.org/10.1016/j.system.2017.01.009

Kigel, R. M., McElvany, N., \& Becker, M. (2015). Effects of Immigrant Background on Text Comprehension, Vocabulary, and Reading Motivation: A Longitudinal Study. Learning and Instruction, 35, 73-84. https://doi.org/10.1016/j.learninstruc.2014.10.001

Korat, O. (2010). Reading electronic books as a support for vocabulary, story comprehension and word reading in kindergarten and first grade. Computers and Education, 55(1), 24-31. https://doi.org/10.1016/j.compedu.2009.11.014

Kweon, S., \& Kim, H. (2008). Beyond raw frequency : Incidental vocabulary acquisition in extensive reading. Reading In, 20(2), 191-215.

Leona, N. L., van Koert, M. J. H., van der Molen, M. W., Rispens, J. E., Tijms, J., \& Snellings, P. (2021). Explaining individual differences in young English language learners' vocabulary knowledge: The role of Extramural English Exposure and motivation. System, 96, 102402. https://doi.org/10.1016/j.system.2020.102402

Li, J., \& Deng, Q. (2018). What Influences the Effect of Texting-based Instruction on Vocabulary Acquisition? Learners' Behavior and Perception. Computers and Education, 125, 284-307. https://doi.org/10.1016/j.compedu.2018.06.017

Liu, J., \& Zhang, J. (2018). The Effects of Extensive Reading on English Vocabulary Learning: A Metaanalysis. Canadian Center of Science and Education, 11(6), 1-15. https://doi.org/10.5539/elt.v11n6p1

Mahdavy, B. (2011). The Role of Topic Familiarity and Rhetorical Organization of Texts in L2 incidental Vocabulary Acquisition. Procedia - Social and Behavioral Sciences, 29, 208-217. https://doi.org/10.1016/j.sbspro.2011.11.226

Malin, J. L., Cabrera, N. J., \& Rowe, M. L. (2014). Low-income minority mothers' and fathers' reading and 
children's interest: Longitudinal contributions to children's receptive vocabulary skills. Early Childhood Research Quarterly, 29(4), 425-432. https://doi.org/10.1016/j.ecresq.2014.04.010

Marzban, A., \& Raeisi, M. R. (2013). The Impact of Personal Life Experiences on the Recall and Retention of Vocabulary in Reading Comprehension of Upper- intermediate EFL Iranian Learners. Procedia - Social and Behavioral Sciences, 70, 956-959. https://doi.org/10.1016/j.sbspro.2013.01.144

Moghadam, S. H., Zainal, Z., \& Ghaderpour, M. (2012). A Review on the Important Role of Vocabulary Knowledge in Reading Comprehension Performance. Procedia - Social and Behavioral Sciences, 66, 555-563. https://doi.org/10.1016/j.sbspro.2012.11.300

Mousavi, F., \& Gholami, J. (2014). Effects of Watching Flash Stories with or without Subtitle and Reading Subtitles on Incidental Vocabulary Acquisition. Procedia - Social and Behavioral Sciences, 98, 12731281. https://doi.org/10.1016/j.sbspro.2014.03.543

Muñoz, C. (2017). Tracing Trajectories of Young Learners: Ten Years of School English Learning. Annual Review of Applied Linguistics, 37, 168-184. https://doi.org/10.1017/S0267190517000095

Neumann, H., Leu, S., McDonough, K., \& Crawford, B. (2020). Improving Students' Source Integration Skills: Does a Focus on Reading Comprehension and Vocabulary Development Work? Journal of English for Academic Purposes, 48, 100909. https://doi.org/10.1016/j.jeap.2020.100909

Noprianto, E., \& Purnawarman, P. (2019). EFL Students' Vocabulary Learning Strategies and their Affixes Knowlegde. Journal of Language and Linguistic Studies, 15(1), 262-275. www.jlls.org

Novita, E., \& Juita, E. N. (2020). The Contribution of Interest in Reading and Vocabulary Mastery on Writing Skills of Observation Results Reports Text for Grade 10 th Students SMA Negeri of Pasaman Regency. Advances in Social Science, Education and Humanities Research, 485(Iclle), 237-243. http://creativecommons.org/licenses/by-nc/4.0/

Nurdiani, S., R, S., \& Abdurahman, A. (2018). The Relationship of Vocabulary and Reading Comprehension in the Writing Skills Descriptive Text Reviewed Gender.International Conferences on Education, Social Science and Technology, 848-853. https://doi.org/10.29210/20181123

Önalan, O. (2005). EFL teachers' perceptions of the place of Culture in ELT: A survey study at four univiersities in Ankara/Turkey. Journal of Language and Linguistic Studies, 1(2), 215-235.

Ong, K. K. W., \& Zhang, L. J. (2018). The Effects of Code-switched Reading Tasks on Late-bilingual EFL Learners' Vocabulary Recall, Retention and Retrieval. System, 72, 13-22. https://doi.org/10.1016/j.system.2017.10.008

Oscarini, S., \& Bhakti, W. (2018). Vocabulary Mastery by Using Storytelling. Journal of Linguistic and English Teaching, 3(1). https://doi.org/http://dx.doi.org/10.24903/sj.v3i1.146

Pecorari, D., Shaw, P., \& Malmström, H. (2019). Developing a New Academic Vocabulary Test. Journal of English for Academic Purposes, 39, 59-71. https://doi.org/10.1016/j.jeap.2019.02.004

Pezoa, J. P., Mendive, S., \& Strasser, K. (2019). Reading Interest and Family Literacy Practices from Prekindergarten to Kindergarten: Contributions from a Cross-lagged Analysis. Early Childhood Research Quarterly, 47, 284-295. https://doi.org/10.1016/j.ecresq.2018.12.014

Pigada, M., \& Schmitt, N. (2006). Ej759833, 18(1), 1-28.

Prawiyogi, A. G., Fitri, A., \& Suhardiman, S. (2020). Use of Big Book Media towards Interest in Reading Elementary School Students. International Journal of Theory and Application in Elementary and Secondary School Education, 2(1), 8-11. https://doi.org/10.31098/ijtaese.v2i1.164

Price, C. J. (2012). A Review and Synthesis of the First 20 Years of PET and fMRI Studies of Heard Speech, Spoken Language and Reading. Neurolmage, 62(2), 816-847. 
https://doi.org/10.1016/j.neuroimage.2012.04.062

Rachman, D. (2018). Students' Interest in Learning English and Reading Understanding Ability Using Story Texts. JELE (Journal of English Language and Education), 4(1), 37. https://doi.org/10.26486/jele.v4i1.428

Rachmawati, U. (2018). Reading Interest of Senior High School Students: a Case Study. Journal of Languages and Language Teaching, 6(1), 17. https://doi.org/10.33394/jollt.v6i1.809

Rahayuningsih, R. (2020). The Effect of Reading Habit and Vocabulary Mastery Toward Students' Reading Comprehension. Wanastra: Jurnal Bahasa Dan Sastra, 12(2), 266-271. https://doi.org/10.31294/w.v12i2.8458

Reynolds, B. L., Shih, Y. C., \& Wu, W. H. (2018). Modeling Taiwanese Adolescent Learners' English Vocabulary Acquisition and Retention: The Washback Effect of the College Entrance Examination Center's Reference Word List. English for Specific Purposes, 52, 47-59. https://doi.org/10.1016/j.esp.2018.08.001

Rumainah. (2018). Undergraduate Students' Reading Interest and Reading Comprehension Achievement in a State Islamic University. Ta'dib:Journal of Islamic Education (Jurnal Pendidikan Islam), 23(1), 54-64. https://doi.org/10.19109/tjie.v23i1.2080

Sanosi, A. B. (2018). The Effect of Quizlet on Vocabulary Acquisition. Asian Journal of Education and ELearning, 6(4), 4-11. https://doi.org/10.24203/ajeel.v6i4.5446

Şen, Y., \& Kuleli, M. (2015). The Effect of Vocabulary Size and Vocabulary Depth on Reading in EFL Context. Procedia - Social and Behavioral Sciences, 199, 555-562. https://doi.org/10.1016/j.sbspro.2015.07.546

Shahraki, S. H., \& Kassaian, Z. (2011). Effects of Learner Interaction, Receptive and Productive Learning Tasks on Vocabulary Acquisition: An Iranian Case. Procedia - Social and Behavioral Sciences, 15, 2165-2171. https://doi.org/10.1016/j.sbspro.2011.04.073

Shelby, L. B., \& Vaske, J. (2008). Understanding Meta-analysis: A Review of the Methodological Literature. Leisure Sciences, 30(2), 96-110. https://doi.org/10.1080/01490400701881366

Sibbritt, D., Peng, W., Lauche, R., Ferguson, C., Frawley, J., \& Adams, J. (2018). Efficacy of Acupuncture for Lifestyle Risk Factors for Stroke: A Systematic Review. PLoS ONE, 13(10), 1-30. https://doi.org/10.1371/journal.pone.0206288

Soriano-Ferrer, M., \& Morte-Soriano, M. (2017). Teacher Perceptions of Reading Motivation in Children with Developmental Dyslexia and Average Readers. Procedia - Social and Behavioral Sciences, 237(June 2016), 50-56. https://doi.org/10.1016/j.sbspro.2017.02.012

Sparapani, N., Connor, C. M. D., McLean, L., Wood, T., Toste, J., \& Day, S. (2018). Direct and Reciprocal Effects among Social Skills, Vocabulary, and Reading Comprehension in First Grade. Contemporary Educational Psychology, 53, 159-167. https://doi.org/10.1016/j.cedpsych.2018.03.003

Spencer, M., \& Wagner, R. K. (2018). The Comprehension Problems of Children With Poor Reading Comprehension Despite Adequate Decoding: A Meta-Analysis. Review of Educational Research, 88(3), 366-400. https://doi.org/10.3102/0034654317749187

Subon, F. (2016). Direct Vocabulary Instruction: The Effects of Contextualized Word Families on Learners' Vocabulary Acquisition. Procedia - Social and Behavioral Sciences, 224(August 2015), 284-291. https://doi.org/10.1016/j.sbspro.2016.05.461

Suk, N. (2017). The Effects of Extensive Reading on Reading Comprehension, Reading Rate, and Vocabulary Acquisition. Reading Research Quarterly, 52(1), 73-89. https://doi.org/10.1002/rrq.152 
Swanson, E., Wanzek, J., Vaughn, S., Fall, A. M., Roberts, G., Hall, C., \& Miller, V. L. (2015). Middle School Reading Comprehension and Content Learning Intervention for Below-Average Readers. Reading and Writing Quarterly, 33(1), 37-53. https://doi.org/10.1080/10573569.2015.1072068

Tager-Flusberg, H. (2015). The Development of English as a Second Language With and Without Specific Language Impairment: Clinical Implications. Journal of Speech, Language, and Hearing Research, 24(2), 1-14. https://doi.org/10.1044/2015

Thompson, C. G., \& von Gillern, S. (2020). Video-game based Instruction for Vocabulary Acquisition with English Language Learners: A Bayesian Meta-analysis. Educational Research Review, 30(May 2019), 100332. https://doi.org/10.1016/j.edurev.2020.100332

Varol, B., \& Erçetin, G. (2016). Effects of Working Memory and Gloss Type on L2 Text Comprehension and Incidental Vocabulary Learning in Computer-Based Reading. Procedia - Social and Behavioral Sciences, 232(April), 759-768. https://doi.org/10.1016/j.sbspro.2016.10.103

Vela, V., \& Rushidi, J. (2016). The Effect of Keeping Vocabulary Notebooks on Vocabulary Acquisition and Learner Autonomy. Procedia - Social and Behavioral Sciences, 232(April), 201-208. https://doi.org/10.1016/j.sbspro.2016.10.046

Vidal, K. (2011). A Comparison of the Effects of Reading and Listening on Incidental Vocabulary Acquisition. Language Learning, 61(1), 219-258. https://doi.org/10.1111/j.1467-9922.2010.00593.x

Walgermo, B. R., Frijters, J. C., \& Solheim, O. J. (2018). Literacy Interest and Reader Self-concept When Formal Reading Instruction Begins. Early Childhood Research Quarterly, 44, 90-100. https://doi.org/10.1016/j.ecresq.2018.03.002

Wasik, B. A., Hindman, A. H., \& Snell, E. K. (2016). Book reading and vocabulary development: A systematic review. Early Childhood Research Quarterly, 37, 39-57. https://doi.org/10.1016/j.ecresq.2016.04.003

Welie, C., Schoonen, R., Kuiken, F., \& van den Bergh, H. (2017). Expository text comprehension in secondary school: for which readers does knowledge of connectives contribute the most? Journal of Research in Reading, 40, S42-S65. https://doi.org/10.1111/1467-9817.12090

Wigfield, A., Eccles, J. S., Fredricks, J. A., Simpkins, S., Roeser, R. W., \& Schiefele, U. (2015). Development of Achievement Motivation and Engagement. In Handbook of Child Psychology and Developmental Science (Issue April 2016). https://doi.org/10.1002/9781118963418.childpsy316

Wulandari, D. (2019). Providing Vocabulary Incidental Learning through Reading. Advances in Social Science, Education and Humanities Research (ASSEHR), 188(Eltlt 2018), 147-151. https://doi.org/10.2991/eltlt-18.2019.30

Yang, Q. F., Chang, S. C., Hwang, G. J., \& Zou, D. (2020). Balancing Cognitive Complexity and Gaming Level: Effects of a Cognitive Complexity-based Competition Game on EFL Students' English Vocabulary Learning Performance, Anxiety and Behaviors. Computers and Education, 148(January), 103808. https://doi.org/10.1016/j.compedu.2020.103808

Yildirim, O. (2008). Turkish EFL learners' readiness for learner autonomy. Journal of Language and Linguistic Studies, 4 (1).

Yousefi, M. H., \& Biria, R. (2018). The Effectiveness of L2 Vocabulary Instruction: A Meta-analysis. AsianPacific Journal of Second and Foreign Language Education, 3(1). https://doi.org/10.1186/s40862-0180062-2

Zaccoletti, S., Altoè, G., \& Mason, L. (2020). Enjoyment, Anxiety and Boredom, and Their Control-Value Antecedents as Predictors of Reading Comprehension. Learning and Individual Differences, 79(February 2019), 101869. https://doi.org/10.1016/j.lindif.2020.101869 
Zhonggen, Y. (2018). Differences in Serious Game-aided and Traditional English Vocabulary Acquisition. Computers and Education, 127(July), 214-232. https://doi.org/10.1016/j.compedu.2018.07.014

Zhou, W., Cui, X., Shi, B., Su, M., \& Cao, M. (2021). The Development of Brain Functional Connectome during Text Reading. Developmental Cognitive Neuroscience, 48, 100927. https://doi.org/10.1016/j.den.2021.100927

\section{AUTHOR BIODATA}

Eka Santi working at Universitas PGRI Kanjuruhan Malang, Indonesia, English Education Department. Her main research interest is EFL Teaching Methodology.

Rachmawati Kholipa working at Universitas PGRI Kanjuruhan Malang, Indonesia, English Education Department. Her research interest is Management and Strategy of Teaching English.

Marina Gratciana Putri working at Universitas PGRI Kanjuruhan Malang, Indonesia, English Education Department. Her main research interest is Computer-Assisted Language Learning.

Mujiono is Assoc. Professor at Universitas PGRI Kanjuruhan Malang, Indonesia, English Education Department. His research interest includes EFL Research Methodology and Applied Linguistics. 